https:/ / doi.org/10.18485/iipe_nsail.2020.ch9

\author{
Anđela ĐUKANOVIĆ 1
}

\title{
NEDRŽAVNI AKTERI I ZAŠTITA LJUDSKIH PRAVA
}

\begin{abstract}
Apstrakt: Nedržavni akteri imaju sve značajniju ulogu u svetlu međunarodne zaštite ljudskih prava. Instrumenti za zaštitu ljudskih prava, počev od Univerzalne deklaracije o ljudskim pravima UN iz 1948. godine, pre svega su usmereni na obavezu država u promociji i zaštiti ljudskih prava a pojedinci, odnosno grupe pojedinaca, primarno se prepoznaju kao potencijalne žrtve povreda ljudskih prava. S tim u vezi je neophodno ispitati ulogu nedržavnih aktera u ugrožavanju ljudskih prava. Pojam nedržavnih aktera je neodređen, i obuhvata niz zaista različitih aktera, ali njegova upotreba proizilazi iz potrebe za preispitivanjem državocentrično postavljenog sistema zaštite ljudskih prava. Ugrožavanje ljudskih prava od strane različitih kompanija je možda najaktuelniji problem, koji tek u poslednje vreme privlači značajniju pažnju, i najčešće se prepoznaje u sferi ekonomskih, socijalnih i kulturnih prava, međutim to ne mora biti slučaj. Moguće je razlikovati nekoliko posebnih oblasti u kojima je zaštita ljudskih prava trenutno najugroženija s obzirom na poslovanje kompanija. Nažalost, države iz različitih razloga često nisu u mogućnosti da utiču na ponašanje ovakvih aktera, iako još uvek prestavljaju aktere koji su glavni nosioci obaveze u zaštiti ljudskih prava. Svest o odgovarajućim dužnostima i odgovornostima nedržavnih aktera postepeno dobija na značaju. Ovde posebnu ulogu imaju pravno neobavezujući dokumenti usvojeni u
\end{abstract}

\footnotetext{
${ }^{1}$ Naučni saradnik, Institut za međunarodnu politiku i privredu, Beograd, E-mail: andjela@diplomacy.bg.ac.rs.

Rad je nastao u okviru naučnoistraživačkog projekta "Srbija i izazovi u međunarodnim odnosima 2020. godine", koji finansira Ministarstvo prosvete, nauke i tehnološkog razvoja Republike Srbije, a realizuje Institut za međunarodnu politiku i privredu tokom 2020. godine.
} 
poslednjih par decenija, ali i pozitivna uloga nevladinih organizacija koje su u izvesnom smislu preuzele ulogu u korigovanju ponašanja kompanija. Ključne reči: ljudska prava, nedržavni akteri, države, kompanije, nevladine organizacije.

\section{UVOD}

Ljudska prava bazirana su na državocentričnoj postavci nastaloj nakon Drugog svetskog rata, u kojoj su države isključivi nosioci odgovornosti za ostvarivanje ljudskih prava. Ideja države je evoluirala kroz pojam individualizma, vodeći do shvatanja slobode kao vrline, koja mora biti zaštićena od strane države. ${ }^{2}$ U Povelji Ujedinjenih nacija se, dakle, u članu 1 stav 3 kao jedan od osnovnih ciljeva Ujedinjenih nacija navodi i „unapređivanje i podsticanje poštovanja prava čoveka i osnovnih sloboda za sve bez obzira na rasu, pol, jezik ili veru", zatim se u članu 55 tačka v) kao cilj Ujedinjenih nacija navodi unapređenje "sveopšteg poštovanja i uvažavanja ljudskih prava kao i osnovnih sloboda za sve bez obzira na rasu, pol, jezik ili veru" ${ }^{3}{ }^{3}$ U članu 56 države članice prepoznaju se kao nosioci obaveze, $t j$. da će $u$ saradnji sa Ujedinjenim nacijama, preduzimati neophodne akcije radi postizanja navedenog cilja. U Univerzalnoj deklaraciji o ljudskim pravima mogu se prepoznati izvesne naznake obaveza drugih subjekata u ostvarivanju ljudskih prava. Prava sadržana u njoj se garantuju "svakome", s tim da se u preambuli navodi da će svaki pojedinac i organ društva, težiti da učenjem i vaspitavanjem doprinese poštovanju ovih prava i sloboda, kao i da obezbedi njihovo opšte i stvarno priznanje i poštovanje. ${ }^{4} \mathrm{U}$ članu 29 stav 1 Univerzalne deklaracije o ljudskim pravima navodi se da "svako ima obaveze prema zajednici u kojoj je jedino moguć slobodan i pun razvitak njegove ličnosti". U članu 29 stav 2 ističe se da se u vršenju svojih prava i sloboda „svako

\footnotetext{
${ }^{2}$ Anumeha Mishra, "State-Centric Approach to Human Rights: Exploring Human Obligations", Revue Quebecoise de Droit International, Hors-srie (decembre 2019), p. 57.

3 "Charter of the United Nations", 24 October 1945, United Nations, 1 UNTS XVI.

4 "Universal Declaration of Human Rights", UN General Assembly, 10 December 1948, 217 A (III).
} 
može podvrgnuti samo onim ograničenjima koja su predviđena zakonom, isključivo u cilju obezbeđenja potrebnog priznanja i poštovanja prava i sloboda drugih, kao i zadovoljenja pravičnih zahteva morala, javnog poretka i opšteg blagostanja". Najzad, u članu 29 stav 3 navodi se da se ova prava ne mogu ostvarivati na način koji je suprotan ciljevima i načelima Ujedinjenih nacija. Član 29 , dakle, na neki način ističe i postojanje odgovarajućih obaveza koje se ne odnose samo na države, ali na neodređen način. Osim toga, ova odredba pre predstavlja putokaz za države do koje mere mogu da utiču na ostvarivanje pojedinih prava i sloboda, tj. do koje mere se ona mogu ograničiti. U preambulama Međunarodnog pakta o građanskim i političkim pravima, i Međunarodnog pakta o ekonomskim socijalnim i kulturnim pravima, takođe se govori o dužnosti svakog pojedinca prema drugome i zajednici kojoj pripada, da se zalaže za unapređenje i poštovanje prava koji su njima predviđeni. ${ }^{5}$ Ipak, uprkos ovim naznakama o obavezi pojedinaca prema drugim pojedincima u ostvarivanju ljudskih prava, ustanovljen je sistem koji se zasniva na isključivoj obavezi država u realizaciji ljudskih prava. Države su, dakle, subjekti koji pristaju da budu obavezani međunarodnim ugovorom, a član 29 Univerzalne deklaracije o ljudskim pravima ne pruža dovoljan osnov za uspostavljanje jasne pravne obaveze drugih subjekata, tj. na vrlo uopšten način samo ukazuje na postojanje ovakvih obaveza. U principu, u okviru Ujedinjenih nacija usvojen je model koji prepoznaje pojedince i grupe pojedinaca kao potencijalne žrtve povreda ljudskih prava, države kao potencijalne zaštitnike i prekršioce ljudskih prava (pre svega $u$ odnosu na sopstvenu populaciju), i koji prepoznaje sve države i Ujedinjene nacije kao nosioce obaveze nadzora nad zaštitom ljudskih prava i njihove promocije. ${ }^{6}$

5 “International Covenant on Civil and Political Rights", UN General Assembly, 16 December 1966, United Nations, Treaty Series, vol. 999, p. 171; “International Covenant on Economic, Social and Cultural Rights", UN General Assembly, 16 December 1966, United Nations, Treaty Series, vol. 993, p. 3.

${ }^{6}$ Zehra Kabasakal Arat, "Looking beyond the State But Not Ignoring It, A Framework of Analysis for Non-State Actors and Human Rights", in: George Andreopoulos, Zehra Kabasakal Arat, Peter Juviler (eds.), Non-state Actors in the Human Rights Universe, Kumarin Press, USA, 2004, p. 4. 
Kada je reč o pojmu nedržavnih aktera, pojedini ovde uključuju nedržavne aktere $u$ najširem mogućem smislu, pa bi se $u$ ovom slučaju moglo postaviti i pitanje granice koja čini nekog aktera državnim, tj. u kojoj meri bi se zahtevalo angažovanje države, jer brojni akteri podrazumevaju učešće predstavnika države ili finansiranje od strane države. ${ }^{7}$ Međutim, ovaj pojam bi se mogao definisati pre svega na negativan način, kao zaista široka grupa aktera koji nisu države. Predmet analize nisu ni nedržavni akteri koji funkcionišu u okviru oružanih sukoba, a koji su primarno predmet interesovanja Međunarodnog humanitarnog prava. Mada, u kontekstu Međunarodnog humanitarnog prava pre svega se pruža zaštita za minimum prava u vreme trajanja oružanih sukoba. ${ }^{8}$ Kao relevantni nedržavni akteri, koji nemaju uobičajene elemente koji se pripisuju državama, u svetlu zaštite ljudskih prava mogu se izdvojiti: međuvladine organizacije, međunarodne nevladine organizacije, kompanije (multinacionalne, transnacionalne i lokalne). Kao posebnu grupu bi možda bilo potrebno izdvojiti sredstva informisanja, koja su takođe u većini slučajeva kompanije rukovođene profitom, čije su informacije dostupne u velikom broju zemalja, koje mogu pored ostvarivanja profita funkcionisati i u cilju zaštite javnog interesa neke države, ali su prisutni i neprofitni vidovi novinarstva. Njihova primarna delatnost, odnosno njihovih zaposlenih, je osnažena slobodom izražavanja, koja ponekad u praksi nije korigovana adekvatnim obavezama, odnosno zaštitom drugih ljudskih prava, iako je to eksplicitno predviđeno Međunarodnim paktom o građanskim i političkim pravima. ${ }^{9}$ Pored ove grupe, ovde se mogu uvrstiti i različite

\footnotetext{
${ }^{7}$ Michael Goodhart, "Human Rights and Non-State Actors, Theoretical Puzzles", in: George Andreopoulos, Zehra Kabasakal Arat, Peter Juviler (eds.), Non-state Actors in the Human Rights Universe, Kumarin Press, USA, 2004, p. 29.

8 Šire o tome: Miloš Jončić, Međunarodnopravni položaj civilnog stanovništva u oružanim sukobima, Institut za međunarodnu politiku i privredu, Beograd, 2019, str. 179-181.

${ }^{9}$ Sloboda izražavanja je možda jedna od retkih koja sadrži eksplicitne obaveze član 19 Međunarodnog pakta o građanskim i političkim pravima predviđa da korišćenje slobode izražavanja podrazumeva i posebne dužnosti i odgovornosti, tj. zakonom se ovo pravo može ograničiti, ukoliko je to neophodno radi poštovanja prava ili ugleda drugih lica, kao i radi zaštite nacionalne bezbednosti, javnog poretka, javnog zdravlja ili morala.
} 
religiozne ustanove i organizacije, organizovane kriminalne grupacije, političke stranke, kao i sami pojedinci. ${ }^{10}$ Najzad, ovde se uvrštavaju i entiteti koji nemaju klasične elemente države, gde nisu prisutni oružani sukobi, ali gde se vrši efikasna kontrola nad teritorijom, uz odsustvo organizovane vlasti (tzv. teritorijalni nedržavni akteri). ${ }^{11}$ Pojedini se zalažu i za obuhvatanje isključivo entiteta koji preduzimaju transnacionalne aktivnosti. $^{12}$

Budući da pojam nedržavnih aktera sugeriše obuhvatanje subjekta koji nisu države, to bi dakle podrazumevalo obuhvatanje i međuvladinih organizacija, koje bi takođe mogle biti izvor povreda ljudskih prava. Međutim, čini se da se one obično nemaju u vidu kada se govori o odgovornosti, odnosno dužnostima nedržavnih aktera u zaštiti ljudskih prava. Objašnjenje verovatno leži u činjenici da su međuvladine organizacije uglavnom dobro poznata forma kroz koju se često realizuje zaštita i promocija ljudskih prava. Kao mogući razlozi neuzimanja $u$ obzir međuvladinih organizacija u sklopu pojma nedržavnih aktera, navodi se i da na neki način deluju kao surogati države, zatim da njihov status u međunarodnom pravu nije mnogo drugačiji od statusa država (kao što je to slučaj sa ostalim nedržavnim akterima), kao i da se njihove aktivnosti smatraju uglavnom benignim. ${ }^{13}$ Međutim, one svakako mogu

${ }^{10}$ Zehra Kabasakal Arat, "Looking beyond the State But Not Ignoring It, A Framework of Analysis for Non-State Actors and Human Rights", op. cit., p. 14. U okviru Evropske unije je, na primer, ovim pojmom obuhvaćena sledeća grupa nedržavnih aktera: privatni sektor, ekonomski i socijalni partneri, uključujući tu i sindikate radnika, i civilno društvo u svim svojim oblicima," The Cotonou Agreement", Signed in Cotonou on 23 June 2000, Revised in Luxembourg on 25 June 2005, Revised in Ouagadougou on 22 June 2010, European Commision, 2014, Article 6.

11 Yael Ronen, "Human Rights Obligations of Territorial Non-State Actors", Cornell International Law Journal, Vol. 46, No. 1, 2013. p. 22.

${ }^{12}$ D. Josselin, W. Wallase, "Non-state Actors in World Politics: A Framework", In: D. Josselin, W. Wallase (eds.), Non-state actors in world politics, Basingstoke, Palgrave, 2001, pp.1-20.

${ }^{13}$ Philip Alston, "The Not-a-cat Syndrome: Can the International Human Rights Regime Accommodate Non-State Actors?", in Alston (ed.), Non State Actors and Human Rights, Oxford University Press, 2005, p. 29. 
direktno ili indirektno uticati na ostvarivanje ljudskih prava, a za pojedine međuvladine organizacije prepoznaje se da su $\mathrm{u}$ tom smislu na lošem glasu. ${ }^{14} \mathrm{Na}$ primer, Svetska banka je nametala naplatu troškova osnovnog obrazovanja, iako je besplatno osnovno obrazovanje na univerzalnom nivou nesporan segment prava na obrazovanje. ${ }^{15}$

U svakom slučaju, može se zaključiti da termin nedržavnih aktera nema jasne granice, i zavisi od konteksta u kojem se koristi. ${ }^{16}$ Kao opravdanje upotrebe termina nedržavnih aktera u sklopu međunarodne zaštite ljudskih prava, izdvajaju se pojave kao što su: privatizacija (budući da je mnogim privatnim akterima postepeno data odgovornost u oblasti socijalne zaštite, zdravstvene zaštite, zatvora, škola i drugih funkcija koje su nekad bile $u$ isključivoj nadležnosti javnog sektora), pokretnost kapitala i tokovi inostranih investicija (globalizacija i široke mogućnosti stranih investicija, liberalizacija trgovine), da posledice liberalizacije trgovine ugrožavaju prava radnika od strane kompanija, kao i sve veći uticaj nevladinih organizacija. ${ }^{17}$

Tačnije, osnovni motiv koji navodi na upotrebu zaista širokog termina nedržavnih aktera u kontekstu zaštite ljudskih prava, jeste nemogućnost $\mathrm{u}$ uspostavljanju odgovornosti pojedinih nedržavnih aktera za kršenje ljudskih prava, zbog gore navedenih procesa. Šira upotreba ovog termina, je proizašla iz potrebe za preispitivanjem navedenog državocentričnog modela zaštite ljudskih prava, iako se njime obuhvata veliki broj raznolikih aktera. Činjenica je da mnogi od njih kroz države snose odgovornost za kršenje ljudskih prava, međutim, uspostavljanje odgovornosti ponekad predstavlja izazov.

${ }^{14}$ Kao primer se navode Svetska trgovinska organizacija, Međunarodni monetarni fond, Svetska banka. Zehra Kabasakal Arat, "Looking beyond the State But Not Ignoring It, A Framework of Analysis for Non-State Actors and Human Rights", op. cit., p. 12.

${ }^{15}$ Tomaševski Katarina. "Has the Right to Education a Future Within the United Nations? A Behind-the-Scenes Account by the Special Rapporteur on the Right to Education 1998-2004", Human Rights Law Review, Vol. 5. Issue 2, pp. 233-236.

${ }^{16}$ Manisuli Ssenyonjo, Economic, Social and Cultural Rights in International Law, Oxford, 2009, p. 108.

${ }^{17}$ Philip Alston, "The Not-a-cat Syndrome: Can the International Human Rights Regime Accommodate Non-State Actors?", op. cit., pp. 17-18. 
Pri tome, treba svakako imati u vidu i potencijalno pozitivne uloge nekih od nedržavnih aktera. Većina ovih aktera bi mogla imati i pozitivnu i negativnu ulogu u zaštiti i promociji ljudskih prava. Mada, uobičajeno je da se, na primer, negativna uloga pripisuje pre svega transnacionalnim kompanijama, koje možda ujedno i predstavljaju osnovni izvor potencijalnog ugrožavanja sistema zaštite ljudskih prava u različitim oblastima. Pozitivna uloga se, sa druge strane, obično pripisuje nevladinim organizacijama, i u tom smislu je možda najznačajnija njihova uloga u korigovanju ponašanja različitih kompanija.

\section{OPŠTA PITANJA}

Pored ranije spomenutih naznaka paralelnih obaveza drugih aktera, osim država, u zaštiti i unapređenju ljudskih prava sadržanih u Univerzalnoj deklaraciji o ljudskim pravima, Međunarodnom paktu o građanskim i političkim pravima i Međunarodnom paktu o ekonomskim socijalnim i kulturnim pravima, mogu se navesti i druge inicijative u ovom smislu. Pre svega tu je Predlog Međuakcionog Saveta Univerzalne deklaracije o dužnostima čoveka iz 1997. godine. ${ }^{18}$ Nakon toga je pod okriljem Organizacije UN za obrazovanje, nauku i kulturu (UNESCO), usvojena Deklaracija o ljudskim dužnostima i odgovornostima 1998. godine. ${ }^{19}$ Iste godine, Generalna skupština Ujedinjenih nacija usvojila je Deklaraciju o pravima i odgovornostima pojedinaca, grupa i organa društva u promociji i zaštiti univerzalno priznatih ljudskih prava i osnovnih sloboda. ${ }^{20} \mathrm{U}$ njoj se u članu 18 navodi da pojedinci, grupe, institucije i nevladine organizacije imaju značajnu ulogu i odgovornost $\mathrm{u}$ očuvanju i unapređenju ljudskih prava i osnovnih sloboda. Ovi pravno neobavezujući dokumenti su neodređeni i više

18 "A Universal Declaration of Human Responsibilities", Proposed by the InterAction Council 1 September 1997, InterAction Council.

19 "The Declaration of Human Duties and Responsibilities", 1998, Valencia.

20 "Declaration on the Right and Responsibility of Individuals, Groups and Organs of Society to Promote and Protect Universally Recognized Human Rights and Fundamental Freedoms", Adopted by General Assembly resolution 53/144 of 9 December 1998, A/RES/53/144. 
ukazuju na postojanje potrebe da se ispita nivo konsenzusa $\mathrm{u}$ oblasti odgovornosti nedržavnih aktera.

Nešto kasnije, u okviru Ujedinjenih nacija usvojena su Pravila o odgovornosti transnacionalnih kompanija i drugih poslovnih preduzeća $\mathrm{u}$ pogledu ljudskih prava. ${ }^{21} \mathrm{U}$ ovom dokumentu je, pored priznavanja primarne obaveze država u promociji i zaštiti ljudskih prava, prepoznata i značajna uloga nedržavnih aktera, a pre svega transnacionalnih i drugih poslovnih preduzeća. Naime, ovi entiteti su dužni da u obavljanju svojih aktivnosti promovišu, osiguraju ispunjenje, poštuju, osiguraju poštovanje i zaštitu ljudskih prava priznatih $u$ međunarodnim i nacionalnim zakonima, uključujući tu prava i interese ranjivih grupa. ${ }^{22}$ Nešto kasnije, $u$ okviru Ujedinjenih nacija usvojena su pravno neobavezujuća Rukovodeća načela o poslovanju i ljudskim pravima. ${ }^{23} \mathrm{U}$ ovom dokumentu je prihvaćena direktna odgovornost transnacionalnih kompanija u zaštiti i promociji ljudskih prava, na sličan način kao u slučaju država. U ovom smislu se mogu razlikovati dva osnovna stanovišta - jedno koje ide ka direktnoj odgovornosti nedržavnih aktera za povrede ljudskih prava na međunarodnom i domaćem nivou, i drugo, da je zaštita ljudskih prava $u$ isključivoj nadležnosti države, odnosno ostvaruje se isključivo kroz države. ${ }^{24}$ Trenutno ipak nije postignut širi konsenzus $u$ pogledu uspostavljanja direktne odgovornosti ovih aktera putem pravno obavezujućeg akta. ${ }^{25}$ Značajno je napomenuti i Nacrt članova o

21 "United Nations Norms on the Responsibilities of Transnational Corporations and Other Business Enterprises with Regard to Human Right", Sub-Commission on the Promotion and Protection of Human Rights, UN ESCOR, 55th sess, Agenda Item 4, UN Doc E/CN.4/Sub.2/2003/12/Rev.2.

22 Ibid., Article 1.

23 "Guiding Principles on Business and Human Rights: Implementing the United Nations 'Protect, Respect and Remedy' Framework", HR/PUB/11/04, 2011, United Nations.

${ }^{24}$ Danwood Mzikenge Chirwa, "The Doctrine of State Responsibility as a Potential Means of Holding Private Actors Accountable for Human Rights", Melbourne Journal of International Law, Vol. 5, No.1, 2004, p. 3.

${ }^{25}$ Treba imati u vidu da se, na primer, u međunarodnim instrumentima kojima se regulišu oružani sukobi uspostavlja direktna odgovornost pojedinih nedržavnih aktera, kao na primer oružanih grupa. 
odgovornosti država za međunarodno protivpravne akte Komisije Ujedinjenih nacija za međunarodno pravo (u daljem tekstu: Nacrt). ${ }^{26}$ Naime, Nacrt predstavlja kodifikaciju pravila međunarodnog prava o odgovornosti država, odnosno opštih uslova pod kojima se prema međunarodnom pravu neka država može smatrati odgovornom za akte činjenja ili nečinjenja. Nacrt se može smatrati prikladnim za primenu i u sferi zaštite ljudskih prava, budući da bilo koja obaveza države, bez obzira na njeno poreklo ili karakter, predstavlja kršenje međunarodnih obaveza (član 12 Nacrta). ${ }^{27}$ U Nacrtu su formulisani i principi koji rukovode pripisivanje nekog ponašanja nedržavnog aktera državi. Kao jedno od značajnijih se svakako može navesti pravilo iz člana 5 Nacrta, gde se ukazuje da će se ponašanje osobe ili entiteta koje nije organ države $u$ izvornom smislu te reči, ali koji je zakonom ovlašćeno od strane države da vrši elemente državne vlasti, smatrati aktom države. U ovu grupu se mogu uvrstiti javna preduzeća, delimično javni entiteti, javne agencije, ali i privatne kompanije, pod uslovom da su domaćim pravom ovlašćeni da vrše elemente državne vlasti. ${ }^{28}$ Ponašanje se može smatrati aktom države i ukoliko je reč o osobi ili grupi koja deluje po uputstvima ili kontrolom te države (član 8 Nacrta). Ponašanje osobe ili grupe osoba će se smatrati aktom države i ukoliko pritom vrše elemente državne vlasti, u odsustvu zvaničnih vlasti, a u okolnostima pod kojima se to može smatrati vršenjem vlasti (član 9 Nacrta). Najzad, ponašanje koje se ne može pripisati državi ipak će se pripisati njoj, ukoliko ga prisvoji kao svoje (član 11 Nacrta). Opšti zaključak koji se može izvesti iz ovih odredaba jeste da se akti nedržavnih aktera mogu pripisati državi, pod uslovom da postoji zadovoljavajući stepen povezanosti između države i ponašanja nedržavnih aktera. ${ }^{29}$

26 "Draft Articles on Responsibility of States for Internationally Wrongful Acts", International law Commision, November 2001, Sipplement No. 10 (A/56/10), chp. IV.E.1.

${ }^{27}$ Danwood Mzikenge Chirwa, "The Doctrine of State Responsibility as a Potential Means of Holding Private Actors Accountable for Human Rights", op. cit., p. 9.

${ }^{28}$ James Crawford, State Responsibility: The General Part, Cambridge University Press, New York, 2103, p. 127

${ }^{29}$ Danwood Mzikenge Chirwa, "The Doctrine of State Responsibility as a Potential Means of Holding Private Actors Accountable for Human Rights", op. cit., p. 9. 
U kontekstu međunarodne zaštite ljudskih prava, i obaveze država da zaštite i promovišu ljudska prava, države dakle imaju obavezu da preduzimaju korake kako bi se postepeno postiglo puno ostvarenje priznatih prava svim odgovarajućim sredstvima, posebno donošenjem odgovarajućih zakonodavnih mera. ${ }^{30}$ Ova obaveza podrazumeva i preduzimanje preventivnih mera kako bi se sprečilo kršenje ljudskih prava od strane nedržavnih aktera, kao i stvaranje i održavanje sistema koji se sastoji od niza zakona, pravila i drugih mera, kako bi pojedinci i grupe bili u mogućnosti da ostvaruju svoja ljudska prava, tj. podrazumeva zaštitu koju država pruža od štetnih aktivnosti nedržavnih aktera. ${ }^{31}$

S tim u vezi, značajno je napomenuti standard dužne pažnje (eng. due diligence), koji se razvio u međunarodnom pravu kroz arbitražne odluke i praksu država krajem XIX i početkom XX veka. ${ }^{32}$ Spomenuti princip se može prepoznati u pojedinim instrumentima za zaštitu ljudskih prava i različitim dokumentima. ${ }^{33} \mathrm{Ali}$, i u slučajevima iz prakse. U ovom smislu se u literaturi kao značajan navodi slučaj iz prakse Međuameričkog suda za ljudska prava. ${ }^{34} \mathrm{U}$ ovom slučaju je ukazano da je odgovornost države za akte privatnih aktera moguća ukoliko se dokaže da država nije pokazala dužnu pažnju u nastojanju da spreči povredu ljudskog prava, odnosno da adekvatno odgovori na ovakvu povredu..$^{35}$ Evropski sud za

${ }^{30}$ Član 2 stav 2 Međunarodnog pakta o građanskim i političkim pravima, član 2 stav 1 Međunarodnog pakta o ekonomskim socijalnim i kulturnim pravima.

${ }^{31}$ Manisuli Ssenyonjo, Economic, Social and Cultural Rights in International Law, op. cit., pp. 110-111.

32 Šire o tome: Jan Hessbruegge, "The Historical Development of the Doctrines of Attribution and Due Diligence in International Law", New York University Journal of International Law and Politics, Vol. 36, No. 4, 2004.

33 "Declaration on the Elimination of Violence against Women", UN General Assmbly, 20 December 1993, A/RES/48/104, Article 4.(c); Council of Europe Convention on preventing and combating violence against women and domestic violence, Istanbul 2011, Council of Europe Treaty Series - No. 210, Article 5. (2), Guiding Principles on Business and Human Rights: Implementing the United Nations 'Protect, Respect and Remedy' Framework (Guiding Principles), UN Doc. HR/PUB/11/04 (2011).

${ }^{34}$ Velaksquez Rodriguez v Honduras, IACtHR, Series C, No. 4, 1988, par.

${ }^{35}$ Ibid., par. 172. 
ljudska prava je, na primer, ukazao da neće svaki rizik od povrede prava na život podrazumevati obavezu države da preduzme mere koje će sprečiti njegovo ostvarivanje. ${ }^{36}$ Usvojen je relativno neodređen standard, gde je potrebno da se utvrdi da vlasti nisu učinile sve što se razumno moglo očekivati kako bi se izbegao rizik za koji su znale ili trebale znati. ${ }^{37}$

Ovde bi možda bilo značajno napraviti i distinkciju između države domaćina, u okviru čijih granica se dešava povreda, i države porekla, iz koje potiče nedržavni akter koji preduzima delatnost kojom se krše ljudska prava $\mathrm{u}$ inostranstvu. ${ }^{38}$ Činjenica je da se obaveza zaštite ljudskih prava primarno vezuje za teritoriju države. ${ }^{39}$ Međutim, u zemljama koje značajno zavise od inostranih ulaganja gde je, na primer, prisutna korupcija u većoj meri, odnosno neefikasno sudstvo, ili možda bolje rečeno u svim zemljama koje pokazuju dozu nemoći pre svega u odnosu na transnacionalne korporacije, ovakav sistem je diskutabilan. On se, dakle, zasniva na sposobnosti države da reguliše ponašanje nedržavnih aktera, koji su često moćniji, ili veštiji od same države. Iako je to često slučaj, ne mora uopšte biti reč o zemljama koje se smatraju siromašnim. S druge strane, tu su države porekla nedržavnih aktera. Kako bi država porekla bila odgovorna, neophodno je dokazati da je praktikovala značajnu kontrolu nad nedržavnim akterom $u$ inostranstvu, ali prema pojedinim mišljenjima, ne i dužnu pažnju da spreči i pruži odgovor na kršenje prava. ${ }^{40}$ Države porekla se često uzdržavaju da preduzmu mere koje im stoje na

${ }^{36}$ Osman v. United Kingdom, Judgment, 28. october 1998, application no. 23451/94, p 116.

${ }^{37}$ Ibid.

${ }^{38}$ Danwood Mzikenge Chirwa, "The Doctrine of State Responsibility as a Potential Means of Holding Private Actors Accountable for Human Rights", op. cit., pp. 26-35.

39 „Države ugovornice ovog Pakta se obavezuju da poštuju i garantuju prava priznata u ovom Paktu svim pojedincima koji se nalaze na njihovoj teritoriji i potpadaju pod njihovu nadležnost bez ikakvog razlikovanja, bez obzira na rasu, boju, pol, jezik, veru, političko ili drugo mišljenje, nacionalno ili socijalno poreklo, imovno stanje, rođenje ili svaku drugu okolnost", Član 2 stav 1 Međunarodnog pakta o građanskim i političkim pravima.

${ }^{40}$ Danwood Mzikenge Chirwa, "The Doctrine of State Responsibility as a Potential Means of Holding Private Actors Accountable for Human Rights", op. cit., p. 33. 
raspolaganju, između ostalog i zbog nerazumevanja domašaja domaćeg zakonodavstva za štete koje nedržavni akteri prouzrokuju u inostranstvu, ali i zbog brige da, pošto je najčešće reč o preduzećima, ona promene svoje sedište i time izazovu niz negativnih posledica za tu državu. ${ }^{41}$

U svakom slučaju, pitanje osnovnih dužnosti i odgovornosti za povrede ljudskih prava je i dalje predmet debata, i uglavnom proizlazi iz nemogućnosti država da izađu na kraj sa nedržavnim akterima koji su često uticajniji ili većoj meri sposobni, odnosno prilagodljiviji od država. Članovi Parlamentarne skupštine Saveta Evrope su, na primer, izrazili stav da postoji prostor za ostvarivanje konsenzusa u sferi osnovnih ljudskih dužnosti i odgovornosti, u skladu sa demokratskim principima i međunarodnim pravom. ${ }^{42}$

U sistemu zaštite ljudskih prava najviše zabrinutosti, ipak, izazivaju transnacionalne i multinacionalne kompanije, zbog čega će im biti posvećena posebna pažnja i to u okviru različitih oblasti delovanja, koje su trenutno možda najaktuelnije.

\section{KOMPANIJE I ZAŠTITA LJUDSKIH PRAVA}

Organizacija sistema zaštite ljudskih prava u okviru Ujedinjenih nacija je dovela do specifične asimetrične zaštite ljudskih prava, $u$ smislu da su građanska i politička prava, imala prioritet u odnosu na ekonomska, socijalna i kulturna prava, budući da je mehanizam žalbi za Međunarodni pakt o građanskim i političkim pravima ustanovljen još 1966. godine. Kada je reč o ekonomskim, socijalnim i kulturnim pravima dugo je bio prisutan skepticizam, pre svega u vezi pitanja da li siromašne države mogu obezbediti svakome ova prava, kao i da li ova grupa prava uopšte može biti predmet konkretnog spora. ${ }^{43}$ Međutim, ovakve dileme nisu više aktuelne u

41 "Report of the Special Representative of the Secretary-General on the issue of human rights and transnational corporations and other business enterprises, John Ruggie", UN doc A/HRC/8/5, 7 April 2008, par. 14.

42 "Fundamental Rights and fundamental duties and responsibilities", Doc. 12287, 14 March 2010, Parliamentary Assembly, Council of Europe.

${ }^{43}$ Miodrag Jovanović, Dragica Vujadinović, Rodoljub Etinski, Democracy and Human Rights in the EU, Maribor/Belgrade, 2009, p. 212. 
pravom smislu te reči, i ekonomska, socijalna i kulturna prava polako dobijaju svoje konkretne obrise u pogledu odgovornosti država, a u prilog tome govori i činjenica da je 2008. godine ustanovljen mehanizam žalbi i za Međunarodni pakt o ekonomskim socijalnim i kulturnim pravima ${ }^{44}$ Često se prepoznaje da su povrede ljudskih prava od strane nedržavnih aktera uglavnom locirane među ekonomskim, socijalnim i kulturnim pravima. Međutim, ovo ne mora uopšte biti slučaj, ali ostaje činjenica da je realizacija ekonomskih, socijalnih i kulturnih nešto složenija. Ipak je još uvek značajan argument da ova prava imaju nešto drugačiju prirodu, jer su mnoge norme još uvek neodređene, a i niz informacija koje su neophodne za njihov efikasan nadzor imaju negativan efekat na njihovo ostvarivanje. ${ }^{45}$

Među akterima koji svakako izazivaju najviše zabrinutosti u pogledu zaštite ljudskih prava su svakako transnacionalna, multinacionalna preduzeća koja posluju izvan granica jedne zemlje. Evropska unija je tako izrazila zabrinutost zbog brojnih slučajeva gde je prisutna intenzivna konkurencija $u$ pogledu ulaganja $u$ tržišta u kojima se ne primenjuju standardi međunarodnog prava u dovoljnoj meri, kao i domaći zakoni, koji su doveli do slučajeva zloupotreba od strane preduzeća, a naročito u zemljama u kojima se ne poštuju ljudska prava. ${ }^{46}$

Kada je reč o direktnoj odgovornosti za kršenje ljudskih prava od strane kompanija koje posluju izvan granica jedne zemlje, kao što je ranije rečeno, prisutni su pravno neobavezujući dokumenti u kojima je prihvaćen ovakav koncept odgovornosti. ${ }^{47}$ Značajna je i Tripartitna Deklaracija o principima $\mathrm{u}$ vezi sa multinacionalnim preduzećima i socijalnom politikom usvojena

${ }^{44}$ Stupio na snagu 2013. godine. "Optional Protocol to the International Covenant on Economic, Social and Cultural Rights", New York, 10 December 2008, A/RES/96/117, General Assebly, sixty-third session.

${ }^{45}$ Audrey R. Chapman, "A Violations Approach for Monitoring the International Covenant on Economic, Social and Cultural Rights", Human Rights Quarterly, Vol 18, No. 1, 1996, p. 30.

46 "European Parliament Resolution on EU Standards for European Enterprises Operating in Developing Countries: Towards a European Code of Conduct", Res. A4-0508/98 (1998), Official Journal C 104, 14/04/1999, P. 0180.

47 "United Nations Norms on the Responsibilities of Transnational Corporations and Other Business Enterprises with Regard to Human Right, Sub-Commission 
od strane Upravnog tela Međunarodne organizacije rada 1977. godine i dopunjena 2000. i 2006. godine, kao i Vodič za multinacionalna preduzeća Organizacije za međunarodnu saradnju i razvoj. ${ }^{48}$ Ipak, odgovornost kompanija se još uvek ostvaruje kroz državu, dakle indirektno, mada ovi pravno neobavezujući dokumenti imaju svoj značaj u prepoznavanju konkretnih dužnosti koje imaju multinacionalne, odnosno transnacionalne kompanije u svom poslovanju. Osnovna ideja je da vremenom ovi dokumenti omoguće prihvatanje direktne odgovornosti na široj osnovi.

U vezi sa odgovornošću i dužnostima kompanija u zaštiti ljudskih prava svakako bi bilo poželjno istaći i pozitivnu ulogu nevladinih organizacija. Naime, bojkoti potrošača koje organizuju nevladine organizacije mogu naneti značajnu štetu kompanijama koje krše ljudska prava i dovesti njihovu reputaciju u pitanje, $i$ čak su pozitivno uticale na kompanije koje zavise od ugleda među potrošačima. ${ }^{49}$ Nevladine organizacije, doduše, nemaju ovako neposredan efekat na kompanije koje proizvode sirovine, odnosno koje ne zavise u istoj meri od potrošača (npr. naftne kompanije, kompanije koje se bave eksploatacijom ruda, gasovodi i sl.), ipak i u ovom slučaju aktivnosti nevladinih organizacija mogu izazvati nesigurnost među investitorima, ili nelagodnost među korisnicima sirovina. ${ }^{50} \mathrm{U}$ tom smislu, nevladine organizacije mogu zaista imati pozitivan efekat $u$ nadzoru nad ponašanjem kompanija. ${ }^{51}$

on the Promotion and Protection of Human Rights", op. cit.; "Guiding Principles on Business and Human Rights: Implementing the United Nations 'Protect, Respect and Remedy' Framework", op. cit.

48 "Tripartite Declaration of Principles concerning Multinational Enterprises and Social Policy", Adopted by the Governing Body of the International Labour Office at its 204th Session (Geneva, November 1977) and amended at its 279th (November 2000), 295th (March 2006) and 329th (March 2017) Sessions, International Labour Office, Geneva; “OECD Guidelines for Multinational Enterprises", Organisation for Economic Co-operation and Development, 2011

${ }^{49}$ James Gunderson, "Multinational Corporations as Non-State Actors in the Human Rights Arena", in: George Andreopoulos, Zehra Kabasakal Arat, Peter Juviler (eds.), Non-state Actors in the Human Rights Universe, Kumarin Press, USA, 2004, pp. 85-86.

50 Ibid.

${ }^{51}$ Nevladine organizacije mogu imati značajan uticaj uopše na zaštitu ljudskih prava, ne samo u odnosu na kompanije. Primera radi, primećeno je da imaju pozitivnu 
Treba imati u vidu i da se u regulisanju odnosa između različitih kompanija i zaštite ljudskih prava situacija često pojednostavljuje, u smislu da se mora imati u vidu i niz faktora koji mogu imati uticaja na poslovne aktivnosti, kao što su veličina kompanije, oblast industrije, tip proizvoda, kao i oblik vlasništva nad kompanijom. ${ }^{52}$

Privatizacija pružanja usluga, koja su se ranije uglavnom nalazile $u$ isključivoj nadležnosti javnog sektora, izazvala je zabrinutosti u pogledu zaštite ljudskih prava. Reč je o pružanju usluga u oblastima kao što su, na primer, zdravstvena zaštita, zatvori, osnovno obrazovanje, distribucija vode, električne energije, grejanja i sl. U ovom slučaju su jasni zakoni u oblastima koje imaju karakter monopola, a koje služe zadovoljenju određenog javnog interesa, od izuzetne važnosti kako bi se utvrdile obaveze preduzeća koja obavljaju ove usluge, tako da privatizacija ne sme podrazumevati isključenje uloge države $u$ ovoj sferi. ${ }^{53}$ Država $u$

ulogu u izveštavanju u slučaju izbijanja epidemije, budući da su države zainteresovane da manipulišu informacijama koje pružaju Svetskoj zdravstvenoj organizaciji. Naime, od 2005. godine bili su prisutni pokušaji da se nevladine organizacije uključe u pirkupljanje podataka koji se pružaju Svetskoj zdravstvenoj organizaciji, međutim primanje ovakvih izveštaja i dalje ostaje složeno pitanje. Sara E. Davies, "Infectious Disease Outbreak Response: Mind the Rights Gap", Medical Law Review, Vol. 25, No. 2, 2017, p. 291. Ponekad izveštaji nevladinih organizacija čak doprinose usvajanju nove regulative. Tako je, na primer, odluka Evropskog suda za ljudska prava u jednom slučaju bila bazirana isključivo na izveštajima nevladinih organizacija, ova odluka je zatim uticala na donošenje slične presude od strane Suda pravde Evropske unije, da bi na kraju uticala na zakonodavstvo EU. M.S.S. v. Belgium and Greece [GC], presuda od 21. januara 2011, godine, predstavka br. 30696/09; C-411/10, N. S. v Secretary of State for the Home Department and Case C-493/10 M. E. and Others v Refugee Applications Commissioner and Minister for Justice, Equality and Law Reform. [2011], ECLI:EU:C:2011:865; “Regulation (EU) No 604/2013 of the European Parliament and of the Council of 26 June 2013. establishing the criteria and mechanisms for determining the Member State responsible for examining an application for international protection lodged in one of the Member States by a third-country national or a stateless person", Official Journal of the European Union, 29.6.2013, L180/31, Article 3 (2).

${ }^{52} \mathrm{Ma}$ Xili, "Advancing Direct Corporate Accountability in International Human Rights Law", Frontiers of Law in China, Vol. 14, No. 2, 2019, p. 237.

${ }^{53}$ Antenor Hallo de Wolf, "Human Rights and the Regulation of Privatized Essential Services", Netherlands International Law Review, Vol. 60, Issue 2, 2013, p. 171. 
ovom slučaju ima obavezu da nadzire ne samo ekonomske efekte ponašanja preduzeća koja pružaju ove usluge, već i socijalne efekte..$^{54}$ Određene osnovne potrebe društva, dakle, moraju adekvatno biti zadovoljene, u skladu sa osnovnim standardima zaštite ljudskih prava, što je obaveza države.

Kao problematična oblast delovanja preduzeća kada je reč o zaštiti ljudskih prava, pre svega se može izdvojiti oblast zaštite prava radnika. Kako bi se privukle strane investicije države često ostvaruju navedeni cilj kroz ugrožavanje prava radnika, odnosno smanjivanje priznatih standarda u ovoj oblasti. ${ }^{55}$ Situacija je daleko od zadovoljavajuće u ovoj oblasti zaštite ljudskih prava. Iako je, na primer, pravo na bezbedne uslove rada, univerzalno priznato ljudsko pravo, prema procenama Međunarodne organizacije rada, oko 2,7 miliona ljudi umre svake godine zbog nebezbednih uslova rada, a najčešće lica koja su zaposlena u preduzećima koja podrazumevaju rad sa toksičnim supstancama. ${ }^{56}$

Takođe, fizičke aktivnosti neke kompanije mogu ugroziti život i zdravlje lokalnog stanovništva, odnosno imati negativne efekte po uživanje bezbedne, čiste i zdrave životne sredine. U Vodiču za multinacionalna preduzeća Organizacije za međunarodnu saradnju i razvoj je posvećena posebna pažnja ponašanju preduzeća u kontekstu zaštite životne sredine. Između ostalog, od kompanija se traži da se uzdrže i od traženja ili prihvatanja izuzetaka od regulative koji nemaju uporište u zakonskom i drugim okvirima koji se odnose na zaštitu ljudskih prava, životnu sredinu, zdravlje, bezbednost i druga pitanja. ${ }^{57}$

\footnotetext{
${ }^{54}$ Ibid., p. 202.

55 "Economic, Social and Cultural Rights: Globalization and Its Impact on the Full Enjoyment of Human Rights: Preliminary Report Submitted by J Oloka-Onyango and Deepika Udagama, in Accordance with Sub-Commission Resolution 1999/8", Sub-Commission on the Promotion and Protection of Human Rights, UN ESCOR, par 34.

56 "The human right to safe and healthy working conditions", United Nations Human Rights Office of the High Commissioner, 23 October 2019. https:/ / www.ohchr.org /EN/NewsEvents/Pages/FifteenPrinciplesProtectWorkers.aspx, 13. 05. 2020.

57 "Guiding Principles on Business and Human Rights: Implementing the United Nations 'Protect, Respect and Remedy' Framework”, op. cit., p. 19.
} 
Ponekad zaštita resursa predstavlja pravi izazov. Privatne kompanije koje se bave eksploatacijom minerala ili nafte ponekad su umešane i u ugrožavanje prava lica koja protestvuju protiv tih kompanija, zbog negativnog uticaja njihovih aktivnosti na uživanje ljudskih prava lokalnih zajednica. ${ }^{58}$

Isto tako, život i zdravlje stanovništva se mogu ugroziti i u drugim oblastima delovanja. Naime, pristup lekovima i oblast kliničkih ispitivanja lekova su takođe značajni. Pravo na zdravlje kao pravo svakoga na najviši mogući standard fizičkog i duševnog zdravlja je predviđeno članom 12. stav 1. Međunarodnog pakta o ekonomskim socijalnim i kulturnim pravima. Svakako, ne bi bilo moguće zahtevati visok nivo zaštite prava na zdravlje ukoliko je reč o nerazvijenoj zemlji koja nema dovoljno sredstava. ${ }^{59}$ Pravo na zdravlje obuhvata i obavezu pružanja lekova koji se smatraju osnovnim. ${ }^{60}$ Da bi neka država mogla da opravda svoj neuspeh $\mathrm{u}$ ispunjenju ove obaveze nedostatkom sredstava, mora dokazati da je učinjen pokušaj da se iskoriste sva dostupna sredstva kako bi se ispunio minimum obaveza. ${ }^{61}$ Specijalni izvestilac o pravu svakoga na uživanje najvišeg mogućeg standarda zdravlja izrazio je zabrinutost u pogledu tržišno orijentisanog pristupa lekovima i visoko konkurentnoj industriji, koja vodi više računa o profitu nego o javnom zdravlju, smatrajući da je uloga država da izbalansiraju ovakav pristup u kontekstu prava na zdravlje i daju prioritet pristupu i

58 "Human rights defenders, Promotion and protection of human rights: human rights questions, including alternative approaches for improving the effective enjoyment of human rights and fundamental freedoms", Note by the SecretaryGeneral, 4 August 2010, United Nations, A/65/223, paras. 10-11.

${ }^{59}$ Depoina Poutakidou, "The right to healthcare in today's challenging world: is justiciability the answer to the existing problems?" , Essay Competition on Health Law, 4th International Focus Programme, ELSA Greece, 2012, p. 5; Tomuschat Christian, Human Rights Between Idealism and Realism, New York, 2008, p. 45.

${ }^{60}$ General Comment No. 14: The Right to the Highest Attainable Standard of Health (Art. 12 of the Covenant), UN Committee on Economic, Social and Cultural Rights (CESCR), 11 August 2000, E/C.12/2000/4. par. 43(d).

61 "General Comment 3, The nature of States parties' obligations", U.N. Doc. E/1991/23, annex III at 86 (1991), Committee on Economic, Social and Cultural Rights, par. 10. 
lekovima u okviru javnog zdravstvenog budžeta. ${ }^{62} \mathrm{U}$ ovoj oblasti je značajno i pravo na dobrobiti od naučnog i tehnološkog napretka. ${ }^{63}$ Postavlja se pitanje - do koje mere učesnici kliničkih ispitivanja u siromašnijim zemljama imaju pravo na dobrobiti od leka u čijem kliničkom ispitivanju su učestvovali, a koje često organizuju farmaceutske kompanije poreklom iz bogatih zemalja? Naime, prisutna je pojava obavljanja istraživanja u zemljama u kojima su niži troškovi njihovog preduzimanja, ograničenja sadržana u zakonima manje restriktivna, i u kojima je prisutan veliki broj naivnih pacijenata koji nisu ranije bili lečeni. ${ }^{64}$ Ovde se istovremeno postavlja i pitanje zaštite patenta, i do koje mere bi kompanije imale obavezu prema licima koja su učestvovala $\mathrm{u}$ kliničkom ispitivanju leka, npr. u smislu besplatnog davanja leka. Ova oblast je nešto detaljnije regulisana na nivou Evrope, ali je broj ratifikacija relevantnog dokumenta već duži niz godina nizak. ${ }^{65}$ U oblasti kliničkih ispitivanja lekova se mora poštovati niz standarda, između ostalog princip slobodnog i informisanog pristanka (niz konkretnih informacija se moraju pružiti ispitanicima), niz zahteva u pogledu prirode istraživanja i njegove bezbednosti, ispitanik mora da ima koristi od istraživanja i sl. Složenost ovih procedura svakako ostavlja značajan prostor za zloupotrebe od strane farmaceutskih kompanija.

Oblast prava potrošača, takođe može biti relevantna. U ovoj oblasti može biti ugroženo pravo na zdravlje, na informaciju, a ponekad i pravo na život. Primera radi - može se navesti decenijama duga debata o bezbednosti genetski modifikovane hrane, ili možda još starija debata, a

62 , Report of the Special Rapporteur on the right of everyone to the enjoyment of the highest attainable standard of physical and mental health, Anand Grover, on access to medicines", A/HRC/23/42, Human Rights Council Twenty-third session, 1 May 2013, pp. 4-5.

${ }^{63}$ Član 27 stav 1 Univerzalne deklaracije o ljudskim pravima, članu 15 stav 1 (b) Pakta o ekonomskim, socijalnim i kulturnim pravima.

64 "Opinion $\mathrm{n}^{\circ} 17$ - Ethical aspects of clinical research in developing countries", European Group on Ethics in Science and new Technologies, 04/02/2003, par. 1.11.

65 "Additional Protocol to the Convention on Human Rights and Biomedicine, concerning Biomedical Research", CETS No. 195, Strasbourg, 25.I.2005. Međutim, ovaj instrument je trenutno ratifikovalo samo 12 država članica Saveta Evrope. 
koja se tiče upotrebe nitrata i nitrita u mesnim prerađevinama. Ovde su već duže vreme prisutne oprečne naučne studije o bezbednosti ili nebezbednosti ovakvih proizvoda $u$ ishrani. $U$ ovakvim slučajevima je teško uspostaviti odgovornost proizvođača, kada ne postoji jasan standard. Naučne studije koje potvrđuju bezbednost ovakvih proizvoda mogle bi se finansirati i od strane samih proizvođača.

Kao potencijalne oblasti zloupotreba mogu se navesti i one koje se povezuju sa razvojem tehnologija. Ovde istaknuto mesto zauzimaju mogućnosti ugrožavanja prava na privatnost $\mathrm{u}$ oblasti informaciono telekomunikacionih tehnologija. U okviru Saveta UN za ljudska prava predviđen i specijalni izvestilac za pravo na privatnost, s obzirom na bojazni pojedinih država od nadzora, a posebno eksteritorijalnog nadzora u masovnim srazmerama, koje može imati negativne efekte po ljudska prava ${ }^{66}$ Međutim, na univerzalnom nivou, osim uopštenog prava na privatnost i slobodu izražavanja, nije usvojen pravno obavezujući instrument koji bi konkretnije regulisao zaštitu ljudskih prava $\mathrm{u}$ ovoj oblasti. ${ }^{67}$ Ovde je posebna osobenost $\mathrm{u}$ ostvarivanju ljudskih prava, tzv. "paradoks privatnosti", odnosno pojava da se pojedinci plaše opasnosti po njihovu ličnu autonomiju i slobodu usled globalizovane obrade podataka od strane država ili kompanija, a sa druge strane često dobrovoljno pristupaju davanju svojih ličnih podataka. ${ }^{68}$ Generalna skupština UN je nedavno usvojila Rezoluciju br. 73/179 o pravu na privatnost $\mathrm{u}$ digitalnoj eri u kojoj, između ostalog, prepoznaje problem mogućnosti zloupotrebe podataka od strane privatnih kompanija. Međutim, s tim u vezi primarno obavezuje države da preduzmu neophodne korake kako bi se zaštitilo pravo na

66 "Human Rights Council creates mandate of Special Rapporteur on the right to privacy", 26 March 2015, Dostupno na: http://www.ohchr.org/EN/News Events/Pages/DisplayNews.aspx?NewsID=15763\&LangID=E, 02. 08. 2015.

${ }^{67} \mathrm{Na}$ nivou Evrope značajna je Konvencija o zaštiti lica u odnosu na automatsku obradu ličnih podataka iz 1981. godine koja ima centralni fokus na zaštiti prava na privatnost pojedinca.

${ }^{68}$ Isabell Büschel, Rostane Mehdi, et al., "Protecting Human Health and Security in Digital Europe: How to Deal with the 'Privacy Paradox'"?, Science and Engineering Ethics, September 2014, Volume 20, Issue 3, p. 642. 
privatnost. ${ }^{69}$ Pružanje usluga u ovoj oblasti često pripada kompanijama koje posluju u velikom broju zemalja, i mogućnost nadzora njihovih aktivnosti od strane država u ovoj sferi je zaista teška. Na primer, pojedine kompanije uspešno izbegavaju i plaćanje poreza. ${ }^{70}$ Često se $u$ podrazumevanim, osnovnim postavkama pojedinih platformi ostavljaju široke mogućnosti praćenja aktivnosti potrošača, odnosno korišćenja ličnih podataka. Pojedine države kao jedino rešenje čak primenjuju radikalni protekcionizam, tj. zabranjuju internet pristup brojnim kompanijama, odnosno platformama. ${ }^{71}$

I $\mathrm{u}$ oblasti biomedicine se mogu prepoznati problemi sa potencijalnim zloupotrebama od strane kompanija. Naime, zaštita ljudskih prava u ovoj oblasti nije adekvatno regulisana zbog nedostatka konsenzusa. Prisutni su doduše pravno neobavezujući dokumenti na univerzalnom nivou, vrlo uopštene prirode. Na nivou Evrope su ipak usvojeni pravno obavezujući dokumenti, takođe sa nedovoljno jasnim standardima, ali i manjim brojem ratifikacija. ${ }^{72} \mathrm{U}$ ovoj oblasti ponekad

69 “Assembly Resolution 73/179 of 17 December 2018 and Council resolution 37/2 of 22 March 2018 on the right to privacy in the digital age", A/RES/73/179.

${ }^{70} \mathrm{U}$ izveštajima se navode neke od najpopularnijih platformi koje izbegavaju poreske obaveze (Amazon, Facebook, Google, Netflix, Apple, Microsoft). Rupert Neate, "New study deems Amazon worst for 'aggressive' tax avoidance", The Guardian, 02. 12. 2019. https:/ / www.theguardian.com/business/2019/dec/02/ new-study-deems-amazon-worst-for-aggressive-tax-avoidance, 15. 05. 2019.

${ }^{71} \mathrm{Na}$ primer Kina je zabranila rad velikom broju platformi, ali i sredstava informisanja koja funkcionišu preko interneta.

${ }^{72} \mathrm{Na}$ univerzalnom nivou: "Universal Declaration on the Human Genome and Human Rights", UNESCO's 29th General Conference on 11 November 1997, Resolution 27 C/5.15; “United Nations Declaration on Human Cloning, United Nations", A/RES/59/280, 23 March 2005; "Universal Declaration on Bioethics and Human Right", 32 C/Res. 24 adopted by UNESCO's General Conference on 19 October 2005, "International Declaration on Human Genetic Data - Social and Human Sciences", adopted by UNESCO's 32nd General Conference on 16 October 2003, 31 C/Res. 22. Na nivou Evrope: "Convention for the Protection of Human Rights and Dignity of the Human Being with regard to the Application of Biology and Medicine: Convention on Human Rights and Biomedicine", Oviedo, 4.4.1997, Council of Europe, ETS No. 164; "Additional Protocol to the Convention on Human Rights and Biomedicine, concerning 
ni same države nisu u potpunosti sigurne na koji način postaviti granice između dozvoljenog i nedozvoljenog ponašanja. Ponekad su i usvojeni dokumenti kontradiktorni. Na primer, u skladu sa članom 13 Konvencije o ljudskim pravima i biomedicini iz 1997. godine, donete pod okriljem Saveta Evrope, intervencija koja je usmerena ka izmenama ljudskog genoma može se preduzeti samo za preventivne, dijagnostičke ili terapeutske svrhe, i samo ukoliko joj nije cilj uvođenje izmena u genomu bilo kojeg potomka. S druge strane, u članu 5 Univerzalne deklaracije o ljudskom genomu i ljudskim pravima predviđa se da je ipak moguće preduzeti istraživanje, lečenje ili dijagnozu, koji utiču na genom nekog lica (doduše samo posle prethodne stroge procene mogućih rizika i koristi). Oblast biomedicine nudi zaista široke mogućnosti profita za kompanije. Prisutan je i, na primer, tzv. „reproduktivni turizam” koji ostavlja mogućnosti zainteresovanim pojedincima da otputuju u zemlju u kojoj su prisutni liberalniji zakoni i da tamo ostvare željeni cilj. Tako je, na primer, moguće da otputuju u zemlju u kojoj selekcija pola nije zabranjena i da plate značajan iznos za spomenutu uslugu. ${ }^{73}$ Takođe, moguće je izbegavanje naslednih genetskih oboljenja kroz različite intervencije, ali i uz uvođenje izmena u genomu potomaka. ${ }^{74}$ Moguće je zamisliti selekciju i komercijalizaciju drugih osobina budućeg deteta, osim pola budućeg deteta u praksi, na primer boje očiju, visine i sl.

Genetic Testing for Health Purposes", Strasbourg, 27.11.2008, Council of Europe (CETS No. 203); "Additional Protocol to the the Convention on Human Rights and Biomedicine on the Prohibition of Cloning Human Beings", Paris, 12.1.1998, Council of Europe, (ETS No. 168); "Additional Protocol to the Convention on Human Rights and Biomedicine, on Transplantation of Organs and Tissues of Human Origin", Strasbourg, 24. 1. 2002, Council of Europe, (ETS No.186); "Additional Protocol to the Convention on Human Rights and Biomedicine, concerning Biomedical Research", Strasbourg, 25.1.2005, Council of Europe, (ETS No.195).

${ }^{73}$ Beth Greenfield, "Couple Spends \$50K to Choose Baby's Sex, Shining Light on Trend", Center for Genetics and Society, 5 December 2014, http:/ / www.geneticsand society.org/article.php?id=8244, 15. 05. 2020.

${ }^{74}$ Hannah Kuchler, "Scientists plead for moratorium after designer babies outcry, Developers of Crispr technique for genome editing also call for halt to experiments on hereditary genes", Financial Times, 13. 03. 2019, https:/ / www.ft.com/content/ 468a1f16-45c9-11e9-a965-23d669740bfb, 02. 05. 2020. 
Poseban problem su genetski testovi upitnog kvaliteta koji se reklamiraju preko interneta, gde ispitanici šalju svoje uzorke na analizu $u$ inostranstvo, a koji mogu imati značajne posledice. Često u ovom slučaju država koja ne dozvoljava ovakav vid testiranja ima ograničene mogućnosti protiv preduzeća koje pruža ovakve usluge. ${ }^{75}$ Ovu i druge pojave u oblasti biomedicine, međunarodna zaštita ljudskih prava gotovo sigurno neće uspeti da predupredi. Malo je verovatno da će se u etički osetljivoj oblasti usvojiti detaljan, pravno obavezujući dokument sa širokim konsenzusom, a kompanije u ovoj oblasti nude širok spektar usluga. Osim toga, izrazito spora reakcija u kakvom-takvom regulisanju pitanja, koja se tiču tehnološkog razvoja, složeno je i jer je teško naknadno zabraniti ponašanje koje je prvobitno široko praktikovano.

\section{ZAKLJUČAK}

Međunarodnopravni poredak još uvek nije spreman za direktnu odgovornost nedržavnih aktera u pravom smislu te reči, na istovetan način kao i u slučaju država. Međutim, svakako su primetni napori u regulisanju ovog pitanja, ispitivanju stepena konsenzusa, i prepoznavanju konkretnih problema u zaštiti od povreda ljudskih prava od strane nedržavnih aktera. Ovo pitanje svakako zavisi i od vrste i oblasti delovanja nedržavnih aktera. U svakom slučaju, kada je reč o

\footnotetext{
${ }^{75} \mathrm{Na}$ primer, $\mathrm{u}$ pravu Republike Srbije genetičko ispitivanje je dopušteno samo u cilju predviđanja ili otkrivanja genetičke bolesti, genetički uslovljene anomalije ili retke bolesti kad na to pacijent izričito pristane $u$ pisanoj formi, odnosno kad na to pristane trudna žena kao pacijent u pogledu dijagnostike embriona ili fetusa (Zakon o prevenciji i dijagnostici genetičkih bolesti, genetički uslovljenih anomalija i retkih bolesti, Sl. glasnik RS, br. 8/2015, čl. 7). U oba slučaja reč o prekršaju, a ista situacija je čak i u slučaju genetskih modifikacija. (Zakon o biomedicinski potpomognutoj oplodnji, Službeni glasnik RS, br. 40/2017 i 113/2017 - dr. zakon, čl. 49, član 67. stav 1; Zakon o prevenciji i dijagnostici genetičkih bolesti, genetički uslovljenih anomalija i retkih bolesti, član 36. Ukoliko je reč o prekršaju koje je učinilo strano pravno lice ono se kažnjava samo za prekršaj učinjen na teritoriji Republike Srbije, i to ukoliko ima poslovnu jedinicu ili predstavništvo u Republici Srbiji (Zakon o prekršajima, Službeni glasnik RS, br. 65/2013, 13/2016. 98/2016 - odluka US, član 31).
} 
nedržavnim akterima, a pre svega preduzećima, norme mekog prava mogu biti od pomoći $u$ formulisanju njihovih konkretnih obaveza $u$ različitim oblastima delovanja. Vremenom, ovo bi trebalo da postane standard ponašanja. Preduzeća, kao entiteti koji su rukovođeni ciljem sticanja profita, često se nalaze u teškoj koegzistenciji sa zaštitom ljudskih prava koja imaju sasvim drugačiju svrhu. Ipak, iako u ograničenom obimu, zaštita ljudskih prava postepeno dobija na značaju i u ponašanju različitih preduzeća, ne samo kroz sve veću svest međunarodne zajednice o ovom problemu u poslednje dve decenije, već i kroz delovanje nevladinih organizacija. Izlaganje multinacionalnih ili transnacionalnih preduzeća negativnoj reputaciji u pogledu neuvažavanja standarda zaštite ljudskih prava, može svakako imati i negativne efekte i po njihovo poslovanje.

U odsustvu direktne odgovornosti kompanija, u oblasti prava radnika i zaštite životne sredine, siromašne države se moraju uporno ohrabrivati da osiguraju zaštitu osnovnih ljudskih prava u slučaju kršenja prava od strane moćnih kompanija. Međutim, u pojedinim oblastima delovanja, a pre svega $u$ oblastima koje su povezane sa napretkom tehnologija, ne postoje jasni standardi u pogledu zaštite ljudskih prava. Mogućnost sticanja profita u ovim sferama preduzeća široko koriste. Kada je reč zaštiti prava na privatnost u oblasti informaciono telekomunikacionih tehnologija, iako je ovde često dovoljan standard univerzalno priznatog prava na privatnost, ipak bi bilo poželjno usvajanje nešto detaljnijeg, pravno obavezujućeg dokumenta na univerzalnom nivou. Međunarodna tela moraju uporno promovisati pre svega pravo na privatnost $u$ ovoj sferi, i upozoravati na nove forme kršenja ovog prava. Zbog nemoći država da pojedinačno izađu na kraj sa ovim entitetima, neophodna je jaka i odlučna zajednička akcija država. Ova akcija bi podrazumevala blagovremeno identifikovanje pretnje, osudu ponašanja kompanija koje krše prava u oblasti informaciono telekomunikacionih tehnologija, i ispitivanje mogućnosti usvajanja detaljnijeg, pravno obavezujućeg akta.

Kada je reč o oblasti biomedicine, zbog oblasti regulisanja koja je etički osetljiva za države, i čestog konflikta pojedinih prava, odnosno usvajanja primata nekog od prava po pojedinom pitanju od strane svake 
države ponaosob, malo je verovatno da će doći do šireg usvajanja konkretnijih, pravno obavezujućih normi. Na sličan način, kao i na primer u slučaju prava na život. Ovo, iako univerzalno priznato pravo, nikada nije jasno definisano u pogledu momenta kada se smatra da život počinje, a sve zbog različitih shvatanja oko prekida trudnoće i vremenskog okvira za njegovo preduzimanje. Moguće je da će doći do ograničenog pomaka po pojedinim pitanjima. Na primer, u oblasti kliničkih ispitivanja lekova ipak bi možda bilo moguće da se usvoji pravno obavezujući dokument na univerzalnom nivou, koji bi predvideo bar minimum prava ispitanika i definisao odgovarajuće osnovne dužnosti farmaceutskih kompanija.

Činjenica da su mnoge države znatno nemoćnije, i zavisne od pojedinih preduzeća, trebala bi da podstakne na veću međunarodnu saradnju između država u zaštiti osnovnih ljudskih prava. Takva saradnja bi morala da ustupi mesto pukom zadovoljavanju ciljeva preduzeća.

\section{LITERATURA}

Alston, Philip, "The Not-a-cat Syndrome: Can the International Human Rights Regime Accommodate Non-State Actors?", in Alston (ed.), Non State Actors and Human Rights, Oxford University Press, 2005, pp. 3-36.

Büschel, Isabell, Mehdi, Rostane, Cammilleri, Anne, Marzouki, Yousri, Elger, Bernice, "Protecting Human Health and Security in Digital Europe: How to Deal with the 'Privacy Paradox'"?, Science and Engineering Ethics, September 2014, Volume 20, Issue 3, pp. 639-658.

Chapman, Audrey, "A Violations Approach for Monitoring the International Covenant on Economic, Social and Cultural Rights", Human Rights Quarterly, Vol 18, No. 1, 1996, pp. 23-66.

Crawford, James, State Responsibility: The General Part, Cambridge University Press, New York, 2103.

Davies, Sara, "Infectious Disease Outbreak Response: Mind the Rights Gap", Medical Law Review, Vol. 25, No. 2, 2017. pp. 270-292.

Goodhart, Michael, "Human Rights and Non-State Actors, Theoretical Puzzles", in: Andreopoulos George, Kabasakal Arat Zehra, Juviler 
Peter (eds.), Non-state Actors in the Human Rights Universe, Kumarin Press, USA, 2004, pp. 23-41.

Greenfield, Beth, "Couple Spends $\$ 50 \mathrm{~K}$ to Choose Baby's Sex, Shining Light on Trend", Center for Genetics and Society, 5 December 2014, $h t t p: / / w w w . g e n e t i c s a n d s o c i e t y . o r g / a r t i c l e . p h p ? i d=8244$

Gunderson, James, "Multinational Corporations as Non-State Actors in the Human Rights Arena", in: Andreopoulos George, Kabasakal Arat Zehra, Juviler Peter (eds.), Non-state Actors in the Human Rights Universe, Kumarin Press, USA, 2004, pp. 77-91.

Hallo de Wolf, Antenor, "Human Rights and the Regulation of Privatized Essential Services", Netherlands International Law Review, Vol. 60, Issue 2, 2013, pp. 165-204.

Hessbruegge, Jan, “The Historical Development of the Doctrines of Attribution and Due Diligence in International Law", New York University Journal of International Law and Politics, Vol. 36, No. 4, 2004, pp. 1-33.

Jončić, Miloš, Međunarodnopravni položaj civilnog stanovništva u oružanim sukobima, Institut za međunarodnu politiku i privredu, Beograd, 2019.

Josselin, D., Wallase, W., "Non-state Actors in World Politics: A Framework", In: D. Josselin, W. Wallase (eds.), Non-state actors in world politics, Basingstoke, Palgrave, 2001, pp. 21-50.

Jovanović, Miodrag, Vujadinović, Dragica, Etinski, Rodoljub, Democracy and Human Rights in the EU, Maribor/Belgrade, 2009.

Kabasakal Arat, Zehra, "Looking beyond the State But Not Ignoring It, A Framework of Analysis for Non-State Actors and Human Rights", in: Andreopoulos George, Kabasakal Arat Zehra, Juviler Peter (eds.), Non-state Actors in the Human Rights Universe, Kumarin Press, USA, 2004, pp. 3-21.

Kuchler, Hannah, "Scientists plead for moratorium after designer babies outcry, Developers of Crispr technique for genome editing also call for halt to experiments on hereditary genes", Financial Times, 13. 03. 2019, https://www.ft.com/content/468a1f16-45c911e9-a965-23d669740bfb 
Mishra, Anumeha, "State-Centric Approach to Human Rights: Exploring Human Obligations", Revue Quebecoise de Droit International, Horssrie (decembre 2019), pp. 49-66.

Mzikenge Chirwa, Danwood, "The Doctrine of State Responsibility as a Potential Means of Holding Private Actors Accountable for Human Rights", Melbourne Journal of International Law, Vol. 5, No. 1, 2004, pp. 1-36.

Poutakidou, Depoina,“"The right to healthcare in today's challenging world: is justiciability the answer to the existing problems?", Essay Competition on Health Law, 4th International Focus Programme, ELSA Greece, 2012, pp. 1-12.

Ronen, Yael, "Human Rights Obligations of Territorial Non-State Actors", Cornell International Law Journal, Vol. 46, No. 1, 2013, pp. 21-50.

Ssenyonjo, Manisuli, Economic, Social and Cultural Rights in International Law, Oxford, 2009.

Tomaševski, Katarina. "Has the Right to Education a Future Within the United Nations? A Behind-the-Scenes Account by the Special Rapporteur on the Right to Education 1998-2004", Human Rights Law Review, Vol. 5. Issue 2, pp. 205-237.

Tomuschat, Christian, Human Rights Between Idealism and Realism, New York, 2008.

Xili, Ma, "Advancing Direct Corporate Accountability in International Human Rights Law", Frontiers of Law in China, Vol. 14, No. 2, 2019, pp. 231-273. 


\section{NON-STATE ACTORS AND HUMAN RIGHTS PROTECTION}

Abstract: Non-state actors have an increasingly important role in the light of international human rights protection. The instruments for the protection of human rights, starting with the UN Universal Declaration of Human Rights from 1948, were primarily aimed at the obligation of states in the promotion and protection of human rights. Individuals or groups of individuals were primarily recognized as potential victims of human rights violations. In this regard, it is necessary to examine the role of non-state actors in endangering human rights. The notion of non-state actors is vague and encompasses a number of truly different actors, but its use stems from the need to reconsider the state-centric system of human rights protection. The endangerment of human rights by various companies is perhaps the most current problem, which has only recently attracted more attention and is most often recognized in the sphere of economic, social, and cultural rights. However, this may not be the case. It is possible to distinguish several special areas in which the protection of human rights is currently the most endangered with regard to the business of companies. Unfortunately, for various reasons, states are often unable to influence the behavior of such actors, although they still represent actors who are the main bearers of human rights obligations. However, awareness of the respective duties and responsibilities of non-state actors is gradually gaining in importance. Legally non-binding documents adopted in the last couple of decades are important in this sense. Also, the positive role of non-governmental organizations in correcting the behavior of companies is of importance.

Keywords: human rights, non-state actors, states, companies, nongovernmental organizations. 